\title{
Effect of sulphur and zinc with and without FYM on yield and yield attributes of mustard [Brassica juncea (L.) Czern and Coss] grown on light textured soil of Kachchh
}

A.H. SIPAI, J.J. PATEL AND N.I. PATEL

Received : 14.08.2015; Revised : 05.10.2015; Accepted : 19.10.2015

MEMBERS OF RESEARCH FORUM:

Corresponding author :

A.H. SIPAI, Centre of Excellence for

Research on Organic Farming, S.D.

Agricultural University, Bhachu,

KACHCHH (GUJARAT) INDIA

Email: rrsbhachau@sdau.edu.in

\section{Co-authors :}

J.J. PATEL AND N.I. PATEL, Centre of

Excellence for Research on Organic

Farming, S.D. Agricultural

University, Bhachu, KACHCHH

(GUJARAT) INDIA

\section{Summary}

A field experiment consisting of 24 treatment combinations of four levels of sulphur $(0,20,40$, $60 \mathrm{~kg} / \mathrm{ha})$ and three levels of Zinc $(0,2.5$ and $5.0 \mathrm{~kg} \mathrm{Zn} / \mathrm{ha})$ and two level of FYM ( 0 and $10 \mathrm{t}$ FYM/ha) was conducted with two consecutive years from 2007-08 and 2008-09 with three replications under Factorial Randomized Block Design at Bhachau-Kachchh to study the effect of $\mathrm{S}$ and $\mathrm{Zn}$ with and without FYM on yield and yield attributes of mustard. Application of $60 \mathrm{~kg} \mathrm{~S} / \mathrm{ha}$ and $5.0 \mathrm{~kg} \mathrm{Zn} / \mathrm{ha}$ along with $10 \mathrm{t} \mathrm{FYM} / \mathrm{ha}$ significantly increased the yield attributes and yield of mustard as compared to control but it was at par with the application of $40 \mathrm{~kg} \mathrm{~S} /$ ha and $5.0 \mathrm{~kg} \mathrm{Zn} / \mathrm{ha}$ along with $10 \mathrm{t} \mathrm{FYM} / \mathrm{ha}$ and maximum economic benefits of gross realization, net realization along with highest $\mathrm{BCR}$ of 4.84:1.

Key words : Economics, FYM, Indian mustard, Sulphur, Yield, Yield attributes, Zinc

How to cite this article : Sipai, A.H., Patel, J.J. and Patel, N.I. (2015). Effect of sulphur and zinc with and without FYM on yield and yield attributes of mustard [Brassica juncea (L.) Czern amd Coss] grown on light textured soil of Kachchh. Asian J. Soil Sci., 10(2) : 191-200. 